\title{
Quantitative Outcomes of a One Health approach to Study Global Health Challenges
}

\author{
Laura C. Falzon, ${ }^{1,2}$ Isabel Lechner, ${ }^{1}$ Ilias Chantziaras, ${ }^{3}$ Lucie Collineau, ${ }^{4}$ \\ Aurélie Courcoul, ${ }^{5}$ Maria-Eleni Filippitzi, ${ }^{3}$ Riikka Laukkanen-Ninios, ${ }^{6}$ \\ Carole Peroz, ${ }^{7}$ Jorge Pinto Ferreira, ${ }^{4}$ Merel Postma, ${ }^{3}$ Pia G. Prestmo, ${ }^{8}$ \\ Clare J. Phythian, ${ }^{9}$ Eleonora Sarno, ${ }^{10}$ Gerty Vanantwerpen, ${ }^{11}$ Timothée Vergne, ${ }^{12,13,14}$ \\ Douglas J. C. Grindlay, ${ }^{15}$ and Marnie L. Brennan ${ }^{16}$ \\ ${ }^{1}$ Veterinary Public Health Institute, University of Bern, Schwarzenburgstrasse 155, 3097 Liebefeld, Switzerland \\ ${ }^{2}$ Institute of Infection and Global Health, University of Liverpool, 8 West Derby Street, Liverpool L69 7BE, UK \\ ${ }^{3}$ Veterinary Epidemiology Unit, Department of Reproduction, Obstetrics and Herd Health, Faculty of Veterinary Medicine, Ghent University, \\ Salisburylaan 133, 9820 Merelbeke, Belgium \\ ${ }^{4}$ SAFOSO, Waldeggstrasse 1, 3097 Liebefeld, Switzerland \\ ${ }^{5}$ Anses, Laboratory of Animal Health, Epidemiology Unit, University Paris Est, 23, Avenue du Général de Gaulle, 94706 Maisons-Alfort Cedex, France \\ ${ }^{6}$ Department of Food Hygiene and Environmental Health, Faculty of Veterinary Medicine, University of Helsinki, P.O. Box 66, 00014 Helsinki, Finland \\ ${ }^{7}$ BIOEPAR, INRA, Oniris, 44307 Nantes, France \\ ${ }^{8}$ School of Veterinary Sciences, University of Bristol, Langford House, Langford, Bristol BS40 5DU, UK \\ ${ }^{9}$ Section for Small Ruminant Research, Faculty of Veterinary Medicine, Institute for Production Animal Clinical Science, Norwegian University of Life \\ Sciences, 4325 Sandnes, Norway \\ ${ }^{10}$ Institute for Food Safety and Hygiene, University of Zurich, Winterthurerstrasse 272, 8057 Zürich, Switzerland \\ ${ }^{11}$ Department of Veterinary Public Health and Food Safety, Faculty of Veterinary Medicine, Ghent University, Merelbeke, Belgium \\ ${ }^{12}$ Veterinary Epidemiology Economics and Public Health group, Royal Veterinary College, London, UK \\ ${ }^{13}$ MIVEGEC Group, Institut de Recherche pour le développement, Montpellier, France \\ ${ }^{14}$ UMR ENVT-INRA IHAP, University of Toulouse, Toulouse, France \\ ${ }^{15}$ Centre of Evidence-based Dermatology, The University of Nottingham, King's Meadow Campus, Nottingham NG7 2NR, UK \\ ${ }^{16}$ Centre for Evidence-based Veterinary Medicine, School of Veterinary Medicine and Science, The University of Nottingham, Sutton Bonington \\ Campus, Loughborough LE12 5RD, UK
}

\begin{abstract}
Having gained momentum in the last decade, the One Health initiative promotes a holistic approach to address complex global health issues. Before recommending its adoption to stakeholders, however, it is paramount to first compile quantitative evidence of the benefit of such an approach. The aim of this scoping review was to identify and summarize primary research that describes monetary and non-monetary outcomes following adoption of a One Health approach. An extensive literature search yielded a total of 42,167 references, of which 85 were included in the final analysis. The top two biotic health issues addressed in these studies were rabies and malaria; the top abiotic health issue was air pollution. Most studies described collaborations between human and animal $(n=42)$, or human and environmental disciplines $(n=41)$; commonly reported
\end{abstract}

Electronic supplementary material: The online version of this article (https://doi. org/10.1007/s10393-017-1310-5) contains supplementary material, which is available to authorized users.

Published online: January 12, 2018

Correspondence to: Laura C. Falzon, e-mail: laura.falzon@liverpool.ac.uk 
interventions included vector control and animal vaccination. Monetary outcomes were commonly expressed as cost-benefit or cost-utility ratios; non-monetary outcomes were described using disease frequency or disease burden measurements. The majority of the studies reported positive or partially positive outcomes. This paper illustrates the variety of health challenges that can be addressed using a One Health approach, and provides tangible quantitative measures that can be used to evaluate future implementations of the One Health approach.

Keywords: One Medicine, Transdisciplinarity, Endemic and emerging infectious diseases, Zoonoses, Non-communicable diseases, Systematic evidence, Scoping review

\section{INTRODUCTION}

The One Health $(\mathrm{OH})$ approach is based on the notion that human, animal, and environmental health are intimately connected and mutually dependent (Rabinowitz et al. 2008; Dixon et al. 2014). Consequently, advocates of this movement describe the need for a holistic and transdisciplinary approach when tackling complex global health issues with high societal values (American Veterinary Medical Association 2008; Greter et al. 2014).

Despite being considered by some as a novel approach, the concept of OH dates back many centuries (Oura 2014; Woods and Bresalier 2014). Several key figures have played an important role in the promotion of this approach, through recognition of the similarities between human and veterinary medical science, the study of zoonoses and vaccine discovery, and the coining of the terms "One Medicine," "One Health," and "Ecohealth" (Day 2010; Zinsstag et al. 2011; Murray et al. 2014; Roberts 2014; Woods and Bresalier 2014). More recent key events in the $\mathrm{OH}$ movement include the publication of the Manhattan Principles recognizing the importance of a holistic approach when tackling both epidemic and epizootic diseases (World Conservation Society 2004) and the signing of the Tripartite Concept Note which puts onus on promoting prevention and control of disease at the human-animalecosystem interface (The FAO-OIE-WHO Collaboration 2010).

While the benefits of such a holistic and integrative movement may seem intuitive, the $\mathrm{OH}$ approach has come under scrutiny for its accountability, particularly since further investment in such collaborative projects will require a change in the way funds are allocated (Cleaveland et al. 2014; Gibbs 2014). Currently, most funds are administered within sectors. Yet, the collaborative approaches and applications encouraged by the $\mathrm{OH}$ movement often require a substantial initial investment which may go well beyond the possibilities of independent sectors or institutions. Therefore, to allow for more researchers to embrace this approach, there is a need to create interministerial platforms which allow for more integrated surveillance and disease control programs involving the animal, human, and environmental sectors, or novel funding mechanisms which will provide and accommodate for this transdisciplinary approach (Häsler et al. 2012; Gibbs 2014). For example, to prevent human disease and mitigate agricultural damages, a solution may lie primarily with more effective animal vaccination programs, requiring commitment and cohesion across disciplines. However, for this paradigm shift to occur, funding agencies and policymakers must be provided with more evidence on the added value and cost-effectiveness of such cross-sectorial approaches (Hodgson and Darling 2011; Häsler et al. 2012; The World Bank 2012; Boden et al. 2014).

Therefore, the aim of this scoping review (SR) was (1) to systematically identify those studies that describe a quantitative outcome when using a $\mathrm{OH}$ approach and (2) to review and qualitatively summarize the health issues addressed, the type of $\mathrm{OH}$ approaches used, and the nature and value of the quantitative outcomes described. The purpose of this study is to create an evidence base of the types of $\mathrm{OH}$ applications, and consequent monetary and non-monetary outcomes accrued.

\section{Methods}

\section{Research Question, Definitions, and Protocol}

This SR was conducted to identify and summarize studies which describe a quantitative outcome when using a $\mathrm{OH}$ approach to address complex global health challenges. The study was performed as a joint project among residents of the European College of Veterinary Public Health. The population of interest within the studies was defined as the 
human and animal population worldwide. The intervention of interest was the "OH approach," defined as "the collaborative efforts of multiple disciplines working locally, nationally and globally to attain optimal health for people, animals and our environment" (American Veterinary Medical Association 2008). The outcome of interest was a "quantitative outcome," measured either in monetary or non-monetary terms (Rusthon 2009; Rushton et al. 2012; Minutes of the expert workshop 2013).

An a priori protocol was developed to define eligibility criteria and procedure after consultation with experts in $\mathrm{OH}$ and veterinary economics. Additional references were used to help structure the SR (Higgins and Green 2008; Centre for reviews and dissemination 2009), which is reported according to PRISMA guidelines (Moher et al. 2009). Screening tools (S1 and S2) were pretested before implementation to ensure clarity of questions.

\section{Literature Search Strategy}

The outline of the methodological activities undertaken is presented in Fig. 1. The search terms presented in Table 1 were used to systematically search four electronic databases: MEDLINE, CAB Abstracts, Embase, and the National Health Service Economic Evaluation Database (NHS EED; UK). The final search was performed on June 5, 2014, and the search strategies used for each database are presented in S3-S6. In addition to the electronic search, a search verification was performed through expert elicitation to help with the identification of relevant studies within the gray literature, and by manually searching references in recent reviews on the topic (Zinsstag et al. 2007; Zinsstag et al. 2011; Häsler et al. 2012; Min et al. 2013).

\section{Study Inclusion Criteria and Screening}

The predetermined criteria for a publication to be eligible for inclusion are given in S1, while the screening strategy followed is shown in Fig. 1. A publication was considered eligible for inclusion if it reported primary research on a quantitative outcome when using a $\mathrm{OH}$ approach, even if not explicitly defined as such, to address complex global health challenges, and was published after 1910. This date was selected based on the setup of the databases, whereby the earliest publication date available was 1910. Primary research was defined as a study where the author(s) collected and/or analyzed data, and included case reports and case series, qualitative studies, observational studies, and experimental studies. Mathematical models and economic studies were included if they were based on field data collected in the same study or elsewhere. References were included if they were in English, German, Italian, Spanish, French, Portuguese, Greek, Dutch, Finnish, Russian, Norwegian, or Swedish; references in other languages were excluded. If no abstract was available, and the title was not sufficiently clear, the publication was included for full-text screening. Discrepancies regarding a publication's eligibility were first resolved among the smaller group of reviewers and, when necessary, through an online discussion with all reviewers involved in this study.

\section{Qualitative Data Extraction and Analysis}

Data extracted from the included publications are shown in S7-S12; these included: (1) bibliographic information and study design characteristics, (2) how the reference was identified, (3) the health issue addressed, (4) the intersectoral approach used (i.e., human-animal vs. human-environment vs. animal-environment vs. human-animalenvironment), (5) the quantitative outcome described, and (6) a quality assessment based on the clarity of the methods. All extracted data were checked for consistency by two of the authors (LCF and MLB), and any disagreements were resolved through discussion between all reviewers.

To allow for further exploration and description of the studies, the following parameters were extracted: (1) continent where the study was performed; (2) whether the country was considered developed or developing, and its income status; (3) whether the disease agent was abiotic or biotic and, in case of the latter, whether it was a bacterium, virus, protozoa, helminth, or insect; (4) whether the health issue was considered a neglected tropical disease (NTD) or not; and (5) the type of transmission. The definitions of these parameters are based on references provided in S13. Descriptive statistics of the study characteristics (e.g., health issue described, type of intervention, and outcome) were performed using Stata (version 13, StataCorp LP, College Station, TX, USA). Due to the heterogeneity of the studies and topics involved, quantitative meta-analyses were not undertaken.

This review was approved by the Ethical Review Committee at the University of Nottingham, UK (Ethics Approval Number: 1328141209). 


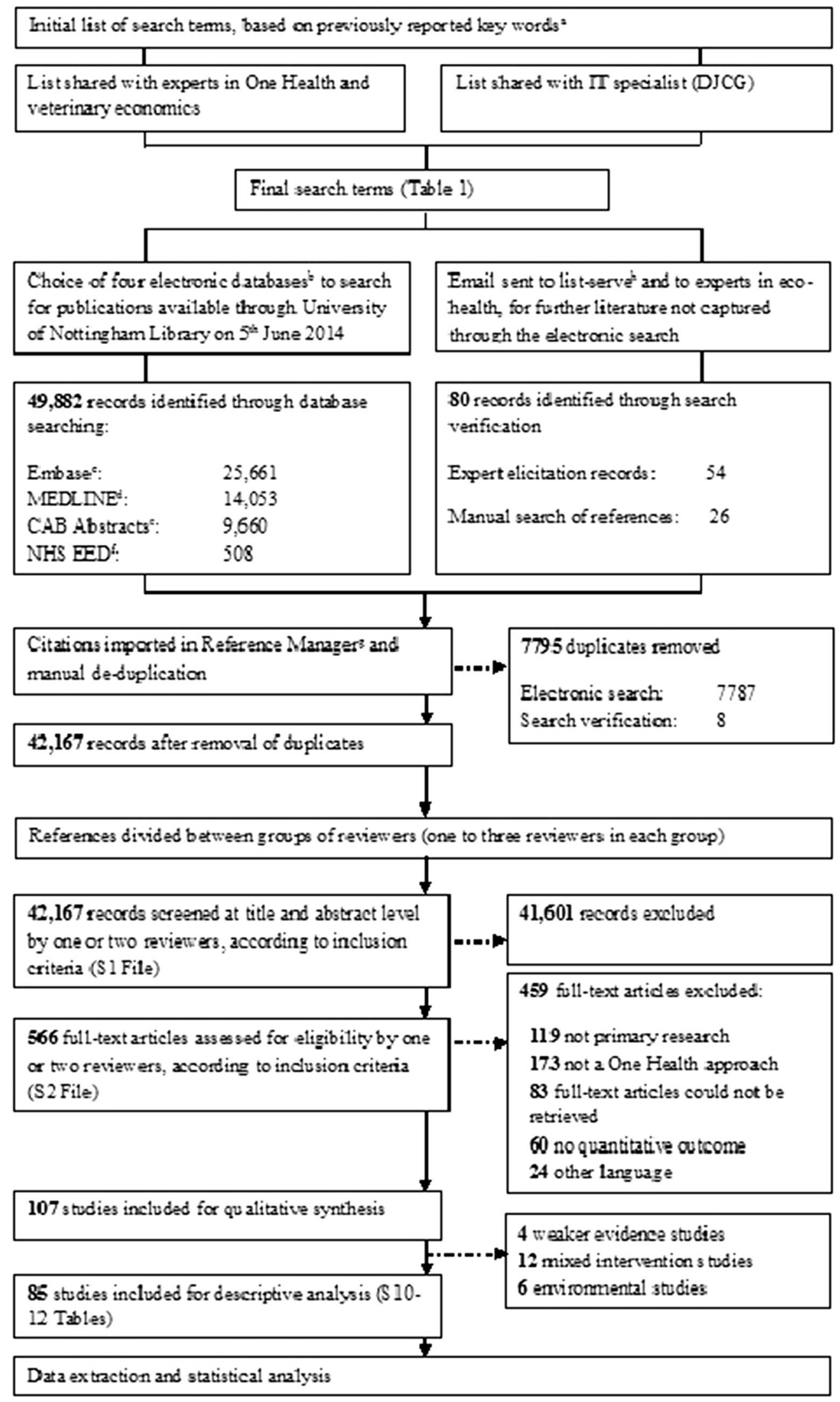


4Fig. 1. Flow of methodological activities and information through the different phases of a scoping review on the quantitative outcome of a One Health approach to address complex global health challenges, as described by the PRISMA guidelines (Moher et al. 2009). ${ }^{a}$ Keywords reported in Rushton 2009; Häsler et al. 2012; Minutes of the Expert Workshop 2013. ${ }^{\mathrm{b}}$ Based on a recommendation that three to five databases are considered sufficient (Young et al. 2014). ${ }^{\mathrm{c}}$ Texts available between 1980 and 2014. ${ }^{\mathrm{d}}$ Texts available between 1946 and 2014. ${ }^{\text {eT }}$ Texts available between 1910 and 2014 . ${ }^{f}$ Part of the National Institute for Health Research Centre for Reviews and Dissemination, UK. ${ }^{\mathrm{g}}$ Refworks ${ }^{\odot}$ (ProQuest, LLC, Cambridge Information Group; Betheseda, MD, USA). ${ }^{\mathrm{h}}$ Community of Practice in Ecosystem Approaches to Health-Canada.

\section{Results}

Figure 1 shows the flow of references through the screening process. Of the 107 studies that were included for quali- tative synthesis, 4 were excluded because they showed elements of a $\mathrm{OH}$ approach, but multiple steps described the link between the $\mathrm{OH}$ approach and quantitative outcome, with certain overarching assumptions not explicitly discussed (S7). Twelve studies were excluded as "Mixed Interventions" because, while they described both interdisciplinary and disciplinary interventions, it was not possible to determine the quantitative outcome specifically due to the $\mathrm{OH}$ approach (S8). Another six studies that described a $\mathrm{OH}$ approach to address environmental health issues were classified separately (S9).

The remaining 85 studies fully met our aim and eligibility criteria (S10-S12); of these, 72 were identified through the electronic search, while 13 were identified through search verification. The studies were performed in all five continents, primarily in Europe $(n=23)$, Asia $(n=20)$, and Africa $(n=16)$. A total of 56 different

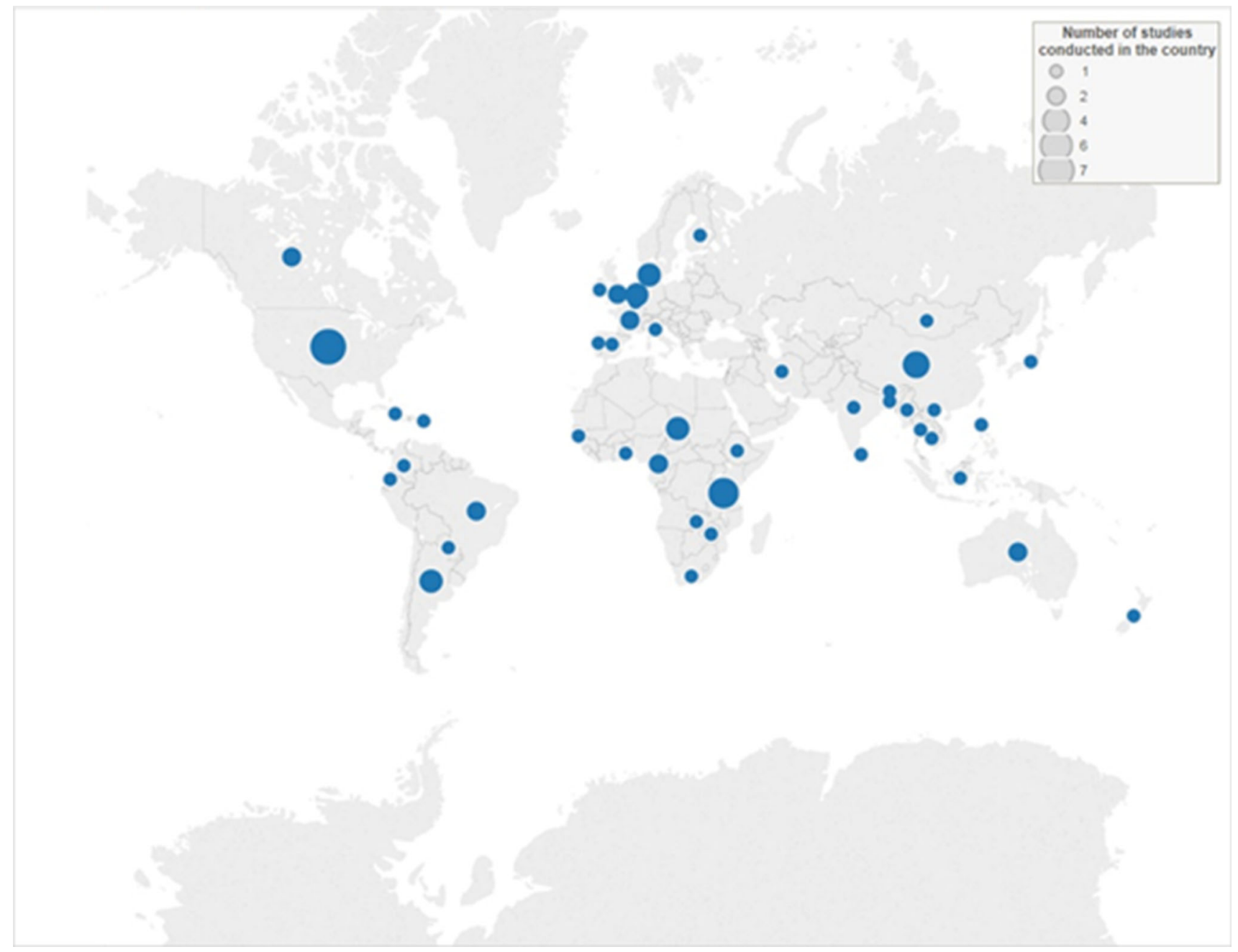

Fig. 2. A world map indicating the number of studies conducted in different countries and included in a scoping review on the quantitative outcome of a One Health approach to address complex global health challenges. 


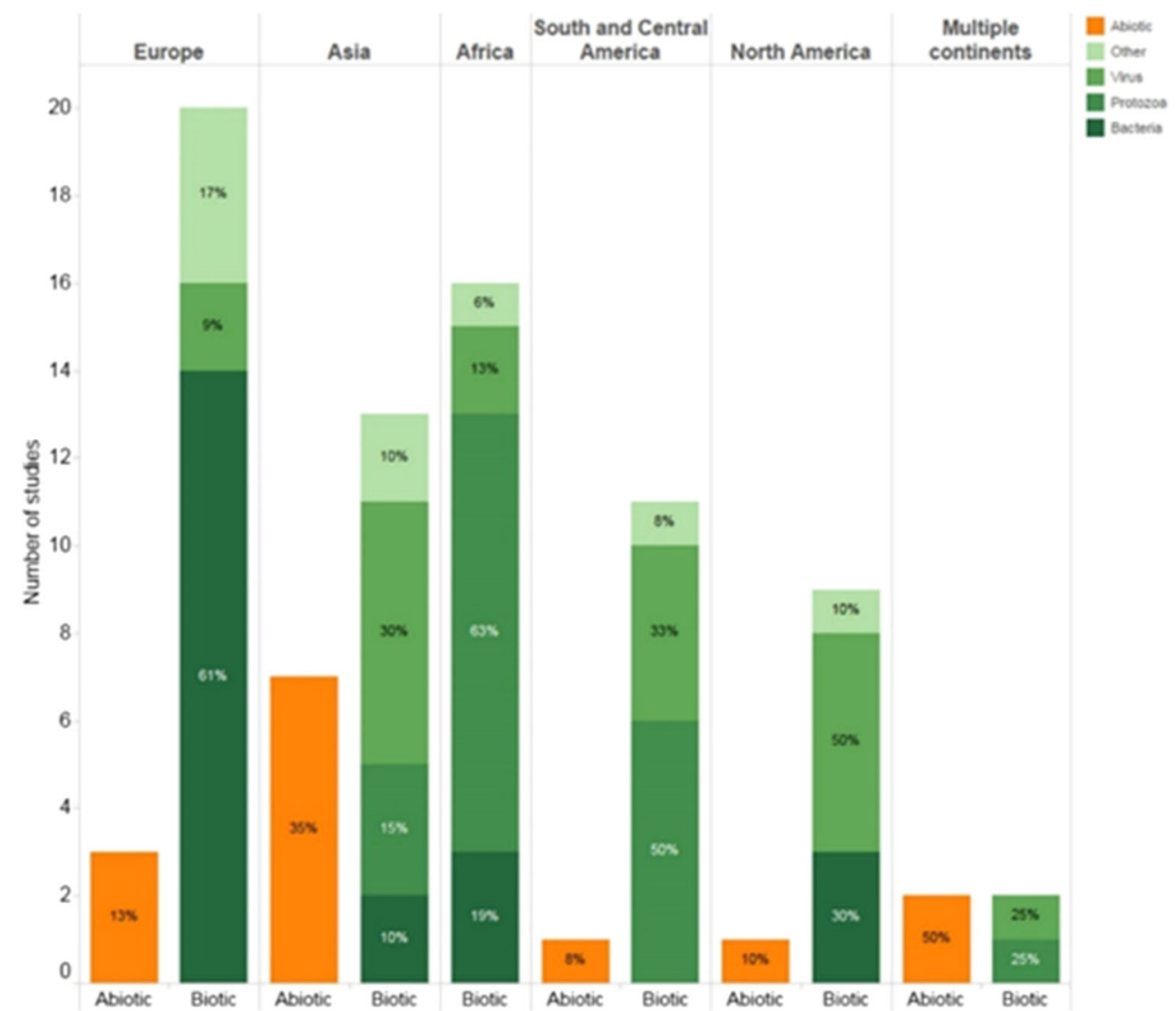

Fig. 3. Abiotic and biotic health issues described, per continent, in a scoping review on the quantitative outcome of a One Health approach to address complex global health challenges. countries or regions were represented (Fig. 2), most commonly the USA $(n=7)$, China $(n=4)$, and Tanzania $(n=4)$. Thirty-six studies were performed in developed countries, while another 44 were performed in developing countries; the remaining 5 studies either did not specify the country, or were performed in countries (Cambodia and Puerto Rico) that did not appear within the reference document used for the classification of developing/developed status (United Nations 2014; see S13). Similarly, 37, 25 , and 14 of these studies were performed in high-, middle-, and low-income countries, respectively.

The publication date of the included studies ranged between 1984 and 2014; the majority $(n=70)$ were published after 2000, of which 33 between 2010 and 2014. The majority of the included references described modeling studies such as economic analyses $(n=42)$, mathematical modeling $(n=12)$, and risk assessments $(n=4)$.

\section{Health Issues Addressed}

The health issues addressed in the 85 studies were classified as biotic $(n=69)$, abiotic $(n=14)$, or both $(n=2$; Figs. 3 and 4).
Among those studies that included a biotic issue, the top five diseases described were rabies $(n=13)$, malaria $(n=11), \quad$ salmonellosis $\quad(n=7), \quad$ campylobacteriosis $(n=6)$, and dengue $(n=6)$. Almost half $(n=32)$ dealt with a NTD such as rabies, dengue, echinococcosis, and Chagas disease. Most of the bacterial studies were performed in Europe $(n=14)$, while most protozoal studies were performed in Africa $(n=10)$.

Air pollution was the most common abiotic health issue addressed $(n=5)$; other issues included pesticides, micro-pollutants in water, and exposure to heavy metals in water or soil. Most of the 14 studies investigating abiotic health issues were conducted after the year 2000 and were performed in Asia $(n=7)$ and Europe $(n=3)$.

\section{One Health Approach}

The majority of these 85 studies either described a collaboration between human and animal $(n=42)$, or between human and environmental $(n=41)$ disciplines. Of all interventions, environmental interventions were the most commonly described, and these targeted vector control $(n=26)$, pollution $(n=8)$, sanitation and water $(n=8)$, 


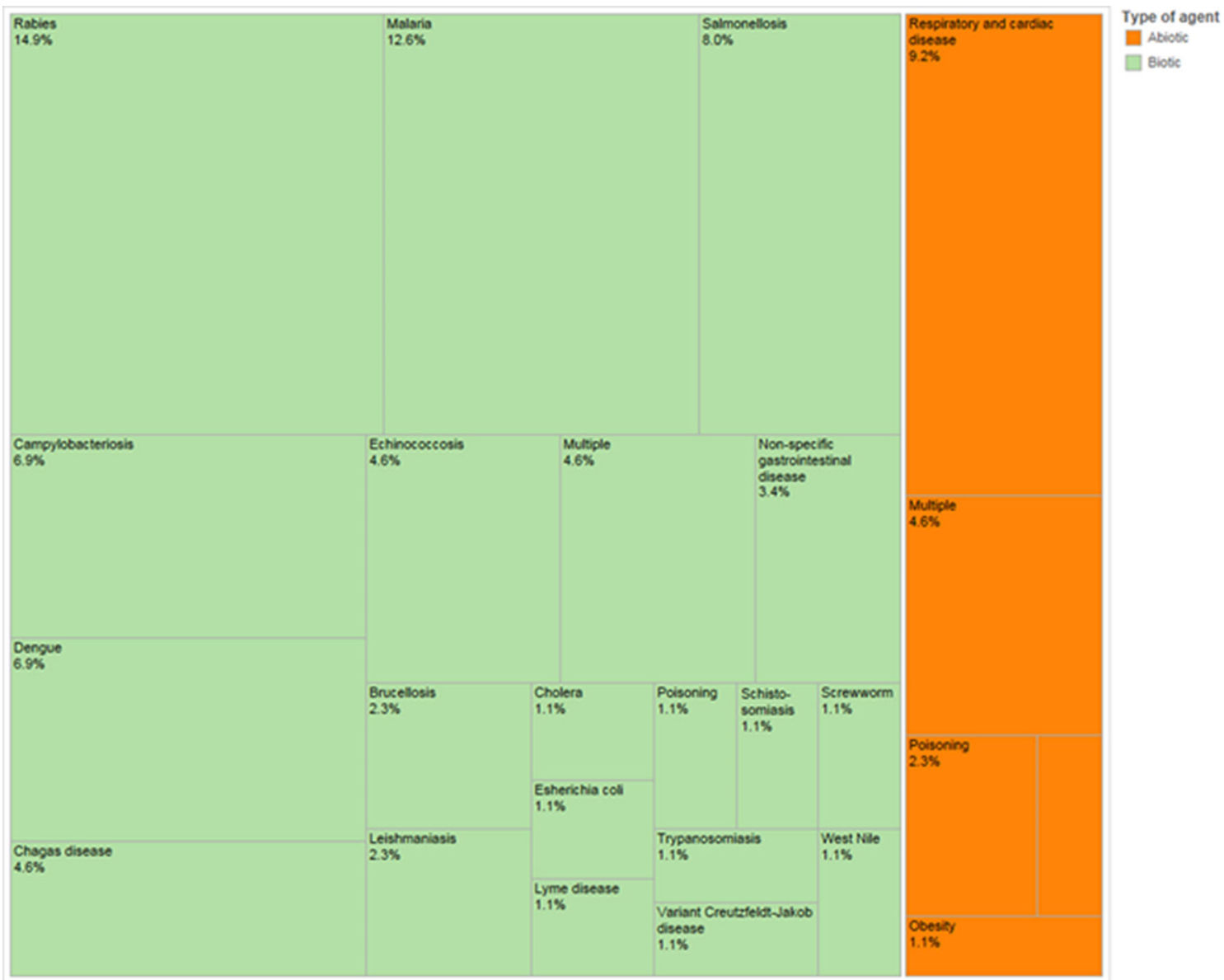

Fig. 4. Abiotic and biotic health issues described in a scoping review on the quantitative outcome of a One Health approach to study complex health challenges.

or modified environmental spaces to encourage physical activity $(n=1)$. More specifically, vector control was achieved primarily through the use of insecticide-treated bed nets, control of breeding sites, and habitat restoration. Pollution and sanitation were largely controlled through policies and structural changes. Other interventions described included vaccination of domestic animals or wildlife (either singly or in combination with other interventions; $n=20$ ), best management practices targeting primary production $(n=12)$, treatment $(n=6)$, integrated surveillance $(n=2)$, and combined human and animal physical activity $(n=2)$.

\section{Quantitative Outcomes}

Of the studies included, some described both monetary and non-monetary outcomes $(n=31)$, while others described only monetary $(n=33)$ or non-monetary $(n=21)$ outcomes (S10-S12).
Most monetary outcomes were described as costbenefit ratios $(n=26)$, cost-utility ratios $(n=18)$, or cost savings $(n=15)$. The majority of the studies had positive ( $n=40)$ or partially positive $(n=18)$ monetary outcomes expressed as positive benefit-cost ratios and net present values, increased cost-utility ratios, or marked cost savings. Only four of the studies had a negative monetary outcome, expressed as negative benefit-to-cost ratios or imbalanced costs.

Among the non-monetary outcomes, measures of disease frequency were the most commonly reported outcome $(n=40)$, followed by measures of disease burden $(n=15)$. Other reported outcomes included vaccination coverage, disease transmission rates, case detection rates, animal and human productivity traits, weight loss, and animal welfare scores. Most studies described positive $(n=43)$ or partially positive $(n=6)$ non-monetary outcomes, such as reduced number of deaths, decreased prevalence, or increased disability-adjusted life years (DA- 


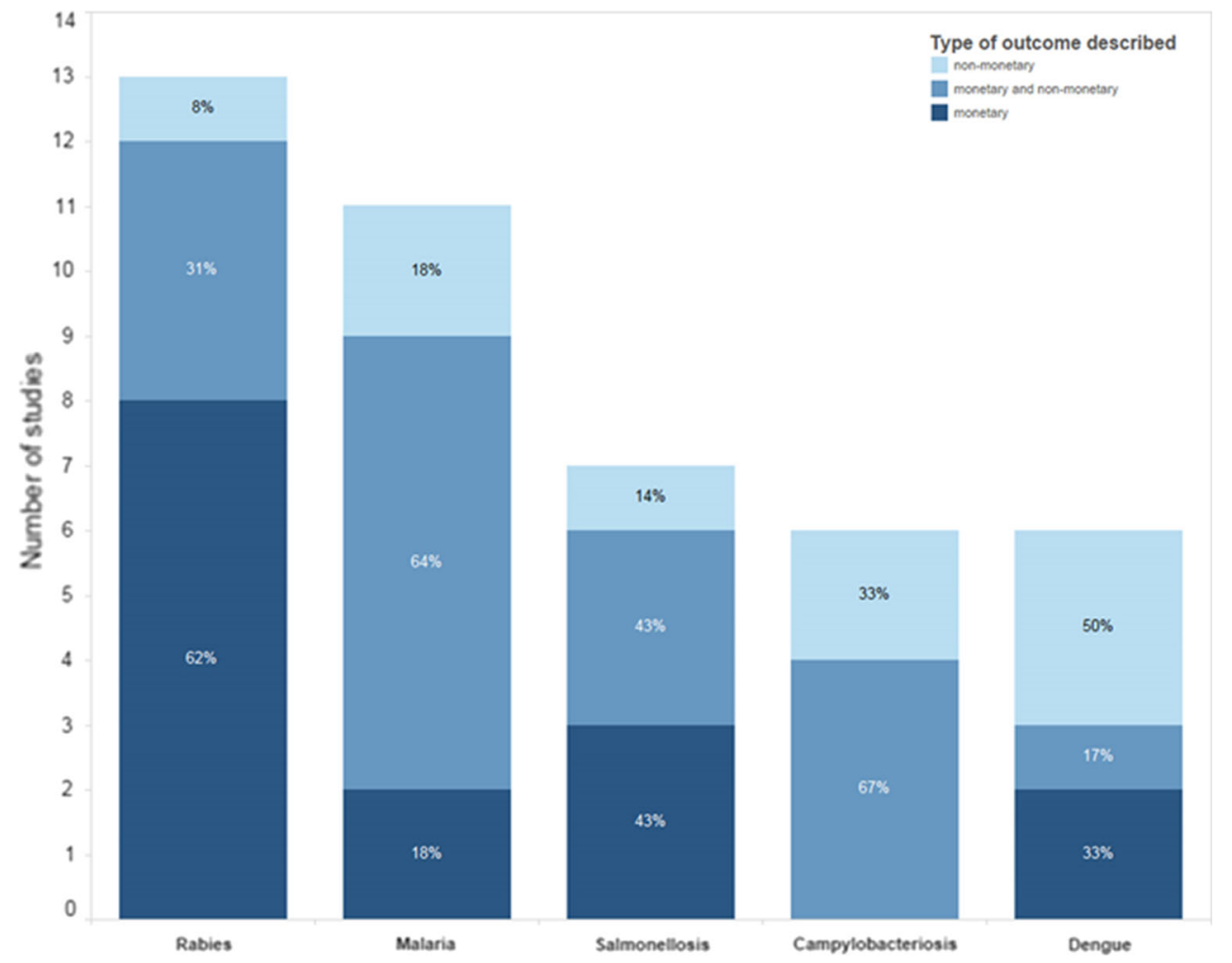

Fig. 5. Proportion of studies that described monetary, nonmonetary, or both outcomes to assess the top five diseases included in a scoping review on the quantitative outcome of a One Health approach to address complex global health challenges.
LYs) saved. Three studies reported no significant difference in outcome between the $\mathrm{OH}$ intervention and control groups.

The quantitative outcomes reported in studies pertaining to the top five diseases were examined in further detail (Fig. 5). The majority of the rabies studies included in this review showed the benefits, in terms of cost savings or deaths averted, that could be accrued through either dog or wildlife vaccination campaigns (Table 2). The foodborne zoonoses' studies illustrated the potential reduction in disease primarily via best management practices at the farm and slaughterhouse level (Tables 3 and 4), while the vector-borne studies illustrated benefits in terms of the interventions' cost-effectiveness or their impact on disease transmission (Tables 5 and 6).

\section{Quality Assessment}

To perform a quality assessment on the included studies, judgement was made as to whether the methods were explicitly stated. The majority of the studies $(n=69)$ were determined to have clearly explained and reproducible methods, while six studies lacked certain information and were therefore considered as partly reproducible. For the remaining ten studies, the methods were considered insufficiently described; there were no recognizable similarities between these studies as they were conducted in different regions and described different health issues (S7-S12).

\section{Discussion}

This study provides an extensive evidence base for research highlighting the quantitative outcomes, both monetary and non-monetary, of an $\mathrm{OH}$ approach. Moreover, it adds to recently published reviews (Häsler et al. 2014a; Baum et al. 2017) by also including research that may not have explicitly included definitions or terminology relating to "One Health" but employed a $\mathrm{OH}$ approach. This work is of substantial importance in relation to decision-making at the policy or governmental level and provides some proof that financing $\mathrm{OH}$ projects can be beneficial in a number of ways. Additionally, this review showcases the approaches used by a number of researchers and organizations that could be utilized in a number of global economic settings to improve human and animal health and welfare.

Most of the included studies dealt with biotic health issues, and the top five diseases were rabies, malaria, salmonellosis, campylobacteriosis, and dengue; this could be driven by funding priorities which are often focused on large global health challenges. Three of these are zoonoses, while the other two are vector-borne diseases. It is not 
Table 1. A List of the Search Terms Used in Four Electronic Databases (MEDLINE, Embase, NHS EED, and CAB Abstracts) to Identify References that Describe a Quantitative Outcome when Using a One Health Approach to Address Complex Global Health Challenges.

((animal AND human) OR (animals and human) OR (animal AND humans) OR (animals AND humans) OR (human AND environment) OR (humans AND environment) OR (animal AND environment) OR (animals AND environment) OR "animal to human" OR "human to animal" OR "social-ecological" OR "socio-ecological” OR “One Health" OR "Ecohealth" OR "One World” OR “One Medicine” OR (ecosystem AND health) OR (holistic AND health) OR (veterinary AND human medicine) OR interdisciplinary OR multidisciplinary OR transdisciplinary OR "cross sector" OR “inter sector” OR "trans sector” OR zoonos* OR zoonotic OR "veterinary public health" OR "VPH” OR "farm to fork" OR "stable to table" OR "value chain")

AND

(DALY* OR HALY* OR QALY^ OR “disability adjusted life year” OR “disability adjusted life years” OR "health adjusted life year” OR "health adjusted life years" OR "quality adjusted life year" OR "quality adjusted life years" OR "expected quality adjusted life year" OR “expected quality adjusted life years” OR “opportunity cost” OR “opportunity costs” OR "cost benefit” OR "cost benefits” OR "cost analys" OR "cost assessment” OR "cost effectiveness" OR “cost utility” OR “cost utilities” OR profit OR "cost allocation” OR "cost benefit analys ${ }^{\star}$ ” OR "cost control” OR “cost controls” OR "cost saving” OR "cost savings" OR "costs savings" OR "cost of illness" OR "costs of illness" OR "cost of disease" OR "costs of disease" OR "cost of intervention" OR "costs of intervention" OR "cost sharing" OR "costs sharing" OR "health care cost" OR "health care costs" OR "health care expenditure" OR "health care expenditures" OR "value of life" OR "societal benefit" economics" OR "resource allocation” OR "cost avoidance” OR “costs avoidance” OR "loss avoidance” OR "losses avoidance”)

surprising that zoonoses would be among the most commonly addressed $\mathrm{OH}$ topics as they are suited for a collaborative approach between human and veterinary medicine, such as through joint human-animal vaccination programs, integrated surveillance, and increased investment in cost-effective animal-level interventions with consequent human health benefits (Roth et al. 2003; Schelling et al. 2007; Zinsstag et al. 2009; Tschopp et al. 2013, Stärk et al. 2015).

Rabies is a clear example where $\mathrm{OH}$ approaches can be beneficial. Thirteen of the included studies described rabies, and all investigated vaccination as an option of controlling rabies in either dogs or wildlife. Most of these studies showed that those control programs that include vaccination are often cost-effective over a long time span, ranging from 4.1 to 11.0 years in the Philippines (Fishbein et al. 1991), 5.9 years in N'Djaména (Zinsstag et al. 2009), and 6 years in Bhutan (Tenzin and Ward 2012).

Our review also identified several $\mathrm{OH}$ interventions targeting food-borne zoonoses, a growing concern due to the increased demand for livestock products and consequent intensification and globalization of the food market (Karesh et al. 2012; Wall 2014). The importance of food safety for the general public and policy-makers was emphasized in a recent document by the European Union Scientific Steering Committee (European Union Scientific Steering Committee 2015) and was reiterated in the choice of Food Safety as the topic for the 2015 World Health Day (Chan 2014). Seven studies described interventions to control salmonellosis in either poultry or pig production systems, and considered the effect of these interventions on the number of human cases and overall costs incurred. Competitive exclusion (Persson and Jendteg 1992), control programs (Kangas et al. 2007; Korsgaard et al. 2009), and management practices such as hot water decontamination of carcasses (Miller et al. 2005; Goldbach and Alban 2006) were all found to be economically effective interventions. Similarly, the other benefits listed for Salmonella and other food-borne diseases such as Campylobacter could be utilized by policy-makers to keep these diseases to a minimum.

Vector-borne diseases, such as malaria and dengue, also featured prominently in our list of included studies. All the malaria studies assessed control programs which included vector control, mostly through the use of insecticide-treated bed nets (ITNs). In several African countries, ITNs (and long-lasting ITNs) proved to be effective in reducing the disease (Goodman et al. 1999; Riedel et al. 2010), though these benefits were sometimes outweighed by the costs incurred (Goodman et al. 2001; PulkkiBrännström et al. 2012). The WHO recommends only distributing long-lasting ITNs (World Health Organization 2007); the findings in the current study are valuable in identifying those interventions that are superior to others 
Table 2. An Overview of the Type and Value of Quantitative Outcomes Featuring in Those Studies that Described One Health Interventions to Address Rabies Included in this Scoping Review.

\begin{tabular}{|c|c|c|c|c|}
\hline References & $\begin{array}{l}\text { Geographical } \\
\text { location }\end{array}$ & Intervention & $\begin{array}{l}\text { Type of quantitative } \\
\text { outcome described }\end{array}$ & Outcome reported \\
\hline \multicolumn{5}{|l|}{$\operatorname{Dogs}$} \\
\hline Bögel and Meslin (1990) & $\begin{array}{r}\text { Developing } \\
\text { countries }\end{array}$ & $\begin{array}{l}\text { Combined dog vaccination } \\
\text { and human } \mathrm{PEP}^{\mathrm{a}}\end{array}$ & Cost efficiency & Cost-efficient in 5 years \\
\hline Fishbein et al. (1991) & Philippines & $\begin{array}{l}\text { One-year dog vaccination } \\
\text { campaign }\end{array}$ & Time to recoup costs & $4.1-11.0$ years \\
\hline Fitzpatrick et al. (2014) & Tanzania & $\begin{array}{l}\text { Annual dog vaccination } \\
\text { campaigns (at different } \\
\text { vaccination coverage) }\end{array}$ & $\begin{array}{l}\text { Number of deaths averted } \\
\text { Percentage of deaths averted } \\
\text { Cost-effectiveness }\end{array}$ & $\begin{array}{l}0.6-2.0 \\
8.3-39.3 \% \\
\text { Cost-effective to very } \\
\quad \text { cost-effective }\end{array}$ \\
\hline Häsler et al. (2014b) & Sri Lanka & $\begin{array}{l}\text { Dog vaccination and other } \\
\text { control interventions }\end{array}$ & $\begin{array}{l}\text { DALYs }{ }^{\mathrm{b}} \text { averted } \\
\text { Animal welfare impact score } \\
\text { Program costs }\end{array}$ & $\begin{array}{l}738 \\
\text { Improved } \\
\text { US\$ } 1.03 \text { million }\end{array}$ \\
\hline Pinto et al. (2011) & Brazil & $\begin{array}{l}\text { Dog vaccination (vs. human } \\
\text { PEP }^{\mathrm{a}} \text { ) }\end{array}$ & Cost comparison & $\begin{array}{l}\text { Costs 9.2-20.2 lower (in } \\
\text { Brazilian Real) }\end{array}$ \\
\hline Tenzin and Ward (2012) & Bhutan & $\begin{array}{l}\text { Combined dog vaccination } \\
\text { and human } \mathrm{PEP}^{\mathrm{a}} \text { (vs. } \\
\text { human } \mathrm{PEP}^{\mathrm{a}} \text { only) }\end{array}$ & Cost savings & $\begin{array}{l}\text { US } \$ 0.09 \text { million saved } \\
\text { after } 6 \text { years }\end{array}$ \\
\hline Townsend et al. (2013) & Bali & $\begin{array}{l}\text { Comprehensive high } \\
\text { coverage dog vaccination }\end{array}$ & $\begin{array}{l}\text { Human lives saved over } 10 \text { years } \\
\text { Money saved over } 10 \text { years }\end{array}$ & $\begin{array}{l}550 \\
\text { US\$ } 15 \text { million }\end{array}$ \\
\hline \multirow[t]{2}{*}{ Zinsstag et al. (2009) } & Chad & $\begin{array}{l}\text { One-year dog vaccination } \\
\text { campaign }\end{array}$ & Cost per death averted & $\begin{array}{l}\text { US\$ } 596 \\
\text { by } 10 \text { th year }\end{array}$ \\
\hline & & & Time to recoup costs & 5.9 years \\
\hline \multicolumn{5}{|l|}{ Wildlife } \\
\hline Aubert (1999) & France & $\begin{array}{l}\text { Wildlife vaccination (vs. fox } \\
\text { depopulation) }\end{array}$ & Cost-benefit analysis & Beneficial after 4 th year \\
\hline $\begin{array}{l}\text { Ministère de la Santé et de la } \\
\text { Protection Sociale } \\
\text { Française (1989) }\end{array}$ & France & $\begin{array}{l}\text { Evaluation of oral } \\
\text { vaccination programs } \\
\text { in wildlife }\end{array}$ & Cost-benefit analysis & $\begin{array}{l}\text { Beneficial in } 10-12 \text { years } \\
\text { (less for some } \\
\text { departments) }\end{array}$ \\
\hline Shwiff et al. (2011) & Canada & $\begin{array}{l}\text { Rabies control program } \\
\text { including fox vaccination }\end{array}$ & $\begin{array}{l}\text { Benefit-cost ratio } \\
\text { Cost savings }\end{array}$ & $\begin{array}{l}0.49-1.36 \\
\text { US } \$ 35.48-98.41 \text { million }\end{array}$ \\
\hline Shwiff et al. (2012) & Canada & $\begin{array}{l}\text { Rabies control programs } \\
\text { including raccoon } \\
\text { vaccination }\end{array}$ & $\begin{array}{l}\text { Benefit-cost ratio } \\
\text { Cost savings }\end{array}$ & $\begin{array}{l}0.96-1.55 \\
\text { US } \$ 46.70-52.93 \text { million }\end{array}$ \\
\hline Uhaa et al. (1992) & USA & $\begin{array}{l}\text { Administration of oral } \\
\text { vaccines to raccoons }\end{array}$ & $\begin{array}{l}\text { Benefit-cost ratio } \\
\text { Cost savings }\end{array}$ & $\begin{array}{l}2.21-6.80 \\
\text { US } \$ 1.95 \text { million }\end{array}$ \\
\hline
\end{tabular}

${ }^{a} P E P$ post-exposure prophylaxis.

${ }^{\mathrm{b}} D A L Y$ s disability-adjusted life years.

when a number are available. These studies also emphasize the importance of environmental interventions, such as vector control, improved sanitation and hygiene, and integrated surveillance programs, to control the human impact of such diseases (World Health Organization 2014).
Increased trade and globalization, together with climate change, habitat encroachment, and forest fragmentation, have augmented the possibility of vector-borne disease transmission (Sherman 2010), and this was exemplified by the recent emergence of Chikungunya and Zika virus in 
Table 3. An Overview of the Type and Value of Quantitative Outcomes Featured in Those Studies that Described One Health Interventions to Address Salmonellosis Included in this Scoping Review.

\begin{tabular}{|c|c|c|c|c|}
\hline References & $\begin{array}{l}\text { Geographical } \\
\text { location }\end{array}$ & Intervention & $\begin{array}{l}\text { Type of quantitative } \\
\text { outcome described }\end{array}$ & Outcome reported \\
\hline $\begin{array}{l}\text { Goldbach and Alban } \\
\text { (2006) }\end{array}$ & Denmark & $\begin{array}{l}\text { Hot water decontamination } \\
\text { of pig carcasses }\end{array}$ & Net present value & $\begin{array}{l}3.5 \text { million Euro over } \\
15 \text { years }\end{array}$ \\
\hline Kangas et al. (2007) & Finland & $\begin{array}{l}\text { Salmonella control } \\
\text { policies in broiler } \\
\text { production }\end{array}$ & Benefit-cost ratio & $0.04-21.25$ \\
\hline \multirow[t]{2}{*}{$\begin{array}{l}\text { Korsgaard et al. } \\
\text { (2009) }\end{array}$} & \multirow[t]{2}{*}{ Denmark } & \multirow[t]{2}{*}{$\begin{array}{l}\text { Salmonella control } \\
\text { programs in egg } \\
\text { production }\end{array}$} & $\begin{array}{l}\text { Number of human } \\
\text { cases averted } \\
\text { Societal costs saved }\end{array}$ & $\begin{array}{l}\text { 10,200 (95\% CI: } \\
8100-12,400) \\
23.3 \text { million Euro }(95 \% \\
\text { CI: } 16.3-34.9)\end{array}$ \\
\hline & & & Cost-benefit ratio & 0.5 \\
\hline \multirow[t]{3}{*}{ Miller et al. (2005) } & \multirow[t]{3}{*}{ USA } & \multirow[t]{2}{*}{ Pig vaccination } & $\begin{array}{l}\text { Reduction in human } \\
\text { cases }\end{array}$ & $60 \%$ \\
\hline & & & Benefit-cost ratio & Less than 1 \\
\hline & & $\begin{array}{l}\text { Pig carcass rinsing at } \\
\text { various water } \\
\text { temperatures }\end{array}$ & Benefit-cost ratio & Greater than 1 \\
\hline $\begin{array}{l}\text { Persson and Jendteg } \\
\text { (1992) }\end{array}$ & $\begin{array}{c}\text { England, Wales } \\
\text { and Sweden }\end{array}$ & $\begin{array}{l}\text { Use of competitive } \\
\text { exclusion in poultry } \\
\text { production }\end{array}$ & Costs of illness saved & Up to 12.6 million GBP \\
\hline $\begin{array}{l}\text { Romero-Barrios et al. } \\
\qquad(2013)\end{array}$ & $\begin{array}{c}\text { European } \\
\text { Union }\end{array}$ & $\begin{array}{l}\text { Interventions on pig farms } \\
\text { and during pig slaughter }\end{array}$ & Risk reduction & Up to $90 \%$ risk reduction \\
\hline Wegener et al. (2003) & Denmark & $\begin{array}{l}\text { Salmonella control } \\
\text { programs in pig and } \\
\text { poultry production }\end{array}$ & Costs saved & US $\$ 25.5$ million \\
\hline
\end{tabular}

Latin America and the Caribbean (World Health Organization 2016a). Cross-sectorial approaches identified in this review could therefore set an example for future endeavors focusing on emerging vector-borne diseases. Ultimately it appears that the magnitude of benefit and the timescale over which control programs must be in place for the realization of benefit is disease and environment dependent. There is value in policy-makers identifying diseases and contexts similar to their own within this review to use as framework for designing programs specific to their own situations.

While the top biotic health issues described in our included studies may reflect funding priorities, they also mirror to a large extent recent findings on the global burden of disease (GBD). Infectious diseases such as rabies, malaria, and dengue are ranked among the top six WHO parasitic and vector-borne diseases (World Health Organization 2016b), and among the top ten NTD by the Lancet (Global Burden Disease 2015 DALYs and HALE Collabo- rators, 2016). Similarly, among all food-borne hazards, campylobacteriosis and salmonellosis, together with enteropathogenic Escherichia coli, were found to be the most relevant contributors to DALYs (World Health Organization Global Burden of Foodborne Diseases 2015). Noticeably, other zoonotic diseases with a high GBD, such as leishmaniasis or schistosomiasis, rarely featured in our findings. Reasons for this might be either that the $\mathrm{OH}$ interventions have not yet been used for their control, or that the study outcome was not assessed in a quantitative manner or it could not be attributed clearly to the $\mathrm{OH}$ intervention. Recent guidelines for $\mathrm{OH}$ studies, which also encourage authors to mention how they think the $\mathrm{OH}$ approach added value to the study, should help by clarifying whether a $\mathrm{OH}$ approach was used in the study and how it contributed to the final outcome (Davis et al. 2017).

In our review, abiotic health issues, such as respiratory disease due to air pollution or metal intoxication, were only described in $16.5 \%$ of the included studies. The importance 
Table 4. An Overview of the Type and Value of Quantitative Outcomes Featured in Those Studies that Described One Health Interventions to Address Campylobacteriosis Included in this Scoping Review.

\begin{tabular}{|c|c|c|c|c|}
\hline References & $\begin{array}{l}\text { Geographical } \\
\text { location }\end{array}$ & Intervention & $\begin{array}{l}\text { Type of quantitative } \\
\text { outcome described }\end{array}$ & Outcome reported \\
\hline \multirow[t]{3}{*}{$\begin{array}{l}\text { Gellynck et al. } \\
\text { (2008) }\end{array}$} & \multirow[t]{3}{*}{ Belgium } & $\begin{array}{l}\text { Decontamination of poultry } \\
\text { carcasses with electrolyzed } \\
\text { oxidizing water }\end{array}$ & Cost-benefit ratio & 17.66 \\
\hline & & $\begin{array}{l}\text { Decontamination of poultry } \\
\text { carcasses with lactic acid }\end{array}$ & & 4.06 \\
\hline & & $\begin{array}{l}\text { Phage therapy used on } \\
\text { chicken farms }\end{array}$ & & 2.54 \\
\hline \multirow[t]{3}{*}{$\begin{array}{l}\text { Havelaar et al. } \\
\text { (2007) }\end{array}$} & \multirow[t]{3}{*}{ The Netherlands } & $\begin{array}{l}\text { Strict hygienic measures on } \\
\text { chicken farms }\end{array}$ & $\begin{array}{l}\text { Cost-effectiveness based } \\
\text { on a cost-utility } \\
\text { ratio }^{\mathrm{a}} \leq \text { Euro } \\
50,000 / \text { DALYs }^{\mathrm{b}}\end{array}$ & Cost-effective \\
\hline & & $\begin{array}{l}\text { Reduced fecal leakage during } \\
\text { carcass processing }\end{array}$ & & Cost-effective \\
\hline & & $\begin{array}{l}\text { Chemical decontamination of } \\
\text { poultry carcasses }\end{array}$ & & Cost-effective \\
\hline $\begin{array}{l}\text { Jensen and Jensen } \\
\text { (2013) }\end{array}$ & European Union & Vaccination of chicks & Cost neutralization & $\begin{array}{l}1.65 \text { Euro per } \\
\text { vaccine dose }\end{array}$ \\
\hline \multirow[t]{3}{*}{ Lake et al. (2013) } & \multirow[t]{3}{*}{ New Zealand } & $\begin{array}{l}\text { Poultry slaughterhouse } \\
\text { improvements (e.g., new } \\
\text { evisceration machines) }\end{array}$ & Cost per DALYs ${ }^{\mathrm{b}}$ saved & NZ\$ 1200 \\
\hline & & $\begin{array}{l}\text { Continuous chemical } \\
\text { treatment of poultry carcass }\end{array}$ & & $\mathrm{NZ \$} 1700$ \\
\hline & & $\begin{array}{l}\text { Phage-based controls on } \\
\text { chicken farms }\end{array}$ & & $\mathrm{NZ} \$ 3000$ \\
\hline $\begin{array}{l}\text { Mangen et al. } \\
\text { (2007) }\end{array}$ & The Netherlands & $\begin{array}{l}\text { Phage therapy used on } \\
\text { chicken farms }\end{array}$ & $\begin{array}{l}\text { Cost-effectiveness based } \\
\text { on a cost-utility } \\
\text { ratio }^{\mathrm{a}} \leq 100,000 \text { Euro/ } \\
\text { DALYs }^{\mathrm{b}}\end{array}$ & Cost-effective \\
\hline \multirow[t]{2}{*}{$\begin{array}{l}\text { Romero-Barrios } \\
\text { et al. (2013) }\end{array}$} & \multirow[t]{2}{*}{ European Union } & $\begin{array}{l}\text { Application of fly screens in } \\
\text { indoor poultry flocks }\end{array}$ & Risk reduction & $60 \%$ \\
\hline & & $\begin{array}{l}\text { Treating or freezing broiler } \\
\text { carcasses }\end{array}$ & & $87-98 \%$ \\
\hline
\end{tabular}

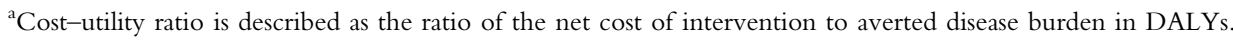

${ }^{\mathrm{b}} D A L Y$ s disability-adjusted life years.

of considering the environmental component of public health was recently reiterated in the Hanoi Declaration (Hanoi Declaration 2015) and subsequent Sustainable Development Goals [particularly non-communicable conditions such as cardiac disease, cancer, and obesity (United Nations 2015)]. Therefore, these cross-sectorial studies that tackle abiotic health issues, such as the impact of air and water pollution on human health, bring to light opportunities and avenues for a collaborative $\mathrm{OH}$ approach which need not be limited to communicable diseases. Two studies included in this review investigated the positive health benefits accrued through dog walking (Bauman et al. 2001; Kushner et al. 2006). Dog ownership encourages owner physical activity and has been described as a cost-effective and socially acceptable preventive measure for the current obesity epidemic (Mills and Hall 2014). This highlights the opportunity for improved disease prevention and control through $\mathrm{OH}$ approaches, by investigating the pivotal hu- 
Table 5. An Overview of the Type and Value of Quantitative Outcomes Featuring in Those Studies that Described One Health Interventions to Address Malaria Included in this Scoping Review.

\begin{tabular}{|c|c|c|c|c|}
\hline References & $\begin{array}{l}\text { Geographical } \\
\text { location }\end{array}$ & Intervention & $\begin{array}{l}\text { Type of quantitative } \\
\text { outcome described }\end{array}$ & Outcome reported \\
\hline \multirow[t]{2}{*}{ Aikins et al. (1998) } & \multirow[t]{2}{*}{ Gambia } & \multirow[t]{2}{*}{ Use of ITN ${ }^{\mathrm{a}}$} & $\begin{array}{l}\text { Cost-effectiveness per death } \\
\text { averted }\end{array}$ & US\$ 471 \\
\hline & & & $\begin{array}{l}\text { Cost-effectiveness per } \\
\text { discounted life years gained }\end{array}$ & US\$ 31.53 \\
\hline \multirow[t]{2}{*}{ Akhavan et al. (1999) } & \multirow[t]{2}{*}{ Brazil } & \multirow{2}{*}{$\begin{array}{l}\text { National malaria control } \\
\text { program including } \\
\text { vector control }\end{array}$} & $\begin{array}{l}\text { Cost-effectiveness per life } \\
\text { saved }\end{array}$ & US\$ 2672 \\
\hline & & & $\begin{array}{l}\text { Cost-effectiveness per } \\
\text { DALYs }^{\mathrm{b}} \text { averted }\end{array}$ & US\$ 69 \\
\hline $\begin{array}{l}\text { Gatton and Cheng } \\
\text { (2010) }\end{array}$ & Australia & ITN $^{\mathrm{a}}$ and chemotherapy & Disease transmission & $\begin{array}{l}\text { No transmission } \\
\text { possible }\end{array}$ \\
\hline \multirow[t]{2}{*}{$\begin{array}{l}\text { Goodman et al. } \\
\text { (1999) }\end{array}$} & \multirow{2}{*}{$\begin{array}{l}\text { Low-income country } \\
\text { in sub-Saharan } \\
\text { Africa }\end{array}$} & Provision of bed nets & \multirow[t]{2}{*}{$\begin{array}{l}\text { Cost-effectiveness per } \\
\text { DALYs }^{\mathrm{b}} \text { averted }\end{array}$} & US\$ $19-85$ \\
\hline & & $\begin{array}{l}\text { Insecticide treatment of } \\
\text { existing bed nets }\end{array}$ & & US\$ 4-10 \\
\hline \multirow[t]{3}{*}{$\begin{array}{l}\text { Goodman et al. } \\
\text { (2001) }\end{array}$} & \multirow[t]{3}{*}{ South Africa } & \multirow[t]{3}{*}{$\begin{array}{l}\text { ITN }^{\mathrm{a}} \text { (vs. residual house } \\
\text { spraying) }\end{array}$} & $\begin{array}{l}\text { Effectiveness (adjusted rate } \\
\text { ratio based on number of } \\
\text { cases) }\end{array}$ & 0.69 \\
\hline & & & Cost per case averted & US\$ 16 \\
\hline & & & Cost per death averted & US\$ 1696 \\
\hline Mueller et al. (2008) & Togo & $\begin{array}{l}\text { Three-year ITN }{ }^{\mathrm{a}} \\
\text { campaign }\end{array}$ & $\begin{array}{l}\text { Number of deaths averted } \\
\text { Number of cases averted } \\
\text { Cost per death averted } \\
\text { Cost per DALYs }{ }^{\text {b }} \text { averted }\end{array}$ & $\begin{array}{l}6285 \\
1.2 \text { million } \\
\text { US\$ } 635 \\
\text { US\$ } 16.39\end{array}$ \\
\hline \multirow[t]{2}{*}{$\begin{array}{l}\text { Mulligan et al. } \\
\text { (2008) }\end{array}$} & \multirow[t]{2}{*}{ Tanzania } & \multirow[t]{2}{*}{$\mathrm{ITN}^{\mathrm{a}}$ voucher program } & $\begin{array}{l}\text { Number of child deaths } \\
\text { averted }\end{array}$ & 12,039 \\
\hline & & & Cost per child death averted & US\$ 873 \\
\hline $\begin{array}{l}\text { Pulkki-Brännström } \\
\text { et al. (2012) }\end{array}$ & Not specified & $\begin{array}{l}\text { Long-lasting ITN }{ }^{\mathrm{a}}(\mathrm{vs} . \\
\left.\text { conventional } \mathrm{ITN}^{\mathrm{a}}\right)\end{array}$ & $\begin{array}{l}\text { Child deaths averted } \\
\text { DALYs }{ }^{\mathrm{b}} \text { averted } \\
\text { Cost per DALYs }{ }^{\mathrm{b}} \text { averted } \\
\text { Cost-effectiveness }\end{array}$ & $\begin{array}{l}30,800 \\
1.02 \text { million } \\
\text { US\$ } 16.8 \\
\text { Cost-effective if } \\
\text { priced at no } \\
\text { more than US\$ } \\
1.5 \text { above } \\
\text { conventional } \\
\text { ITN }^{\mathrm{a}}\end{array}$ \\
\hline Riedel et al. (2010) & Zambia & Bed nets & Odds of parasitaemia & $40 \%$ less $(12-60 \%)$ \\
\hline Smithuis et al. (2013) & Myanmar & $\begin{array}{l}\text { ITN }^{\mathrm{a}} \text { (vs. early diagnosis } \\
\text { and effective treatment) }\end{array}$ & Cost per DALYs ${ }^{\mathrm{b}}$ averted & US\$ 51 \\
\hline $\begin{array}{l}\text { Yhdego and Majura } \\
\text { (1988) }\end{array}$ & Tanzania & $\begin{array}{l}\text { Comparison of two vector } \\
\text { control programs: } \\
\text { engineering vs. use of } \\
\text { larvicides and } \\
\text { insecticides }\end{array}$ & $\begin{array}{l}\text { Program effectiveness } \\
\text { Cost-effectiveness }\end{array}$ & $\begin{array}{l}97 \text { vs. } 75 \% \\
\text { Tshs } 2.8 \text { million vs. } \\
\text { Tshs } 10.5 \text { million }\end{array}$ \\
\hline
\end{tabular}


Table 6. An Overview of the Type and Value of Quantitative Outcomes Featured in Those Studies that Described One Health Interventions to Address Dengue Included in this Scoping Review.

\begin{tabular}{|c|c|c|c|c|}
\hline References & $\begin{array}{l}\text { Geographical } \\
\text { location }\end{array}$ & Intervention & $\begin{array}{l}\text { Quantitative outcome } \\
\text { described }\end{array}$ & Values reported \\
\hline Díaz (2012) & Cuba & $\begin{array}{l}\text { Integrated surveillance } \\
\text { system }\end{array}$ & Detection of febrile cases & Increased \\
\hline $\begin{array}{l}\text { McConnell and } \\
\text { Gubler (2003) }\end{array}$ & Puerto Rico & $\begin{array}{l}\text { Control of vector } \\
\text { breeding sites }\end{array}$ & Cost-effectiveness & $\begin{array}{l}\text { Cost-effective if dengue } \\
\text { transmission is reduced } \\
\text { by } 50 \% \text { and intervention } \\
\text { costs less than US\$ } 2.50 \\
\text { per person }\end{array}$ \\
\hline $\begin{array}{l}\text { Ocampoa et al. } \\
\text { (2014) }\end{array}$ & Colombia & $\begin{array}{l}\text { Identification and } \\
\text { spraying of vector } \\
\text { breeding sites }\end{array}$ & $\begin{array}{l}\text { Rate ratio of human } \\
\text { incidence }\end{array}$ & $\begin{array}{l}0.19(95 \% \text { CI } 0.12-0.30) \\
\text { compared to control } \\
\text { area }\end{array}$ \\
\hline $\begin{array}{l}\text { Orellano and Ped- } \\
\text { roni }(2008)\end{array}$ & Argentina & Fumigation of vectors & $\begin{array}{l}\text { Net present value } \\
\text { Cost-benefit analysis }\end{array}$ & $\begin{array}{l}\text { I\$ } 196,879 \\
\text { Beneficial when more than } \\
1363 \text { cases of dengue } \\
\text { and at least } 1 \text { case of } \\
\text { dengue hemorrhagic } \\
\text { fever are averted }\end{array}$ \\
\hline \multirow[t]{2}{*}{ Suaya et al. (2007) } & Cambodia & $\begin{array}{l}\text { Annual targeted larvicidal } \\
\text { campaigns }\end{array}$ & $\begin{array}{l}\text { Cost per DALYs }{ }^{\mathrm{a}} \text { saved } \\
\text { (public perspective) }\end{array}$ & US\$ 313 \\
\hline & & & $\begin{array}{r}\text { Cost per DALYs }{ }^{\mathrm{a}} \text { saved } \\
(\text { societal perspective })\end{array}$ & US\$ 37 \\
\hline $\begin{array}{l}\text { Tsunoda et al. } \\
\text { (2013) }\end{array}$ & Vietnam & $\begin{array}{l}\text { Use of insecticide-treated } \\
\text { nets to cover water } \\
\text { reservoirs } \\
\text { Addition of insecticide to } \\
\text { other water containers }\end{array}$ & Human seroprevalence & $\begin{array}{l}62.2 \% \text { (vs. } 74.6 \% \text { in } \\
\text { control area) }\end{array}$ \\
\hline
\end{tabular}

${ }^{a} D A L Y s$ disability-adjusted life years.

man-animal companionship relationship to combat not only obesity, but also depression and cognitive disorders.

Antimicrobial resistance (AMR) did not feature in any of our included studies. This was surprising given both the attention it has received in recent years, and its complex and multifaceted nature which makes it amenable to crosssectorial approaches (Queenan et al. 2016; Singh 2017; World Health Organization 2017). Since our literature search was conducted in 2014, it is likely the more recent focus on AMR in published research in the last few years would not have been captured. Similarly, we may have missed studies that describe a $\mathrm{OH}$ approach when dealing with other health issues, such as salmonellosis and trypanosomiasis, but were published after our final literature search was conducted (Sundström et al. 2014; Shaw et al. 2015).
The majority of the 85 studies included for qualitative synthesis were performed after 2000. This is not surprising as the $\mathrm{OH}$ initiative has been gaining momentum over the past decade, and the amount of interdisciplinary research has been shown to be increasing (Stärk et al. 2015; Van Noorden 2015). Nonetheless, segregation between disciplines still persists, particularly between the veterinary and ecological sciences (Manlove et al. 2016), and future interdisciplinary studies should ensure that the ecosystem component is properly represented (Barrett and Bouley 2015). Most identified studies described modeling approaches, either as mathematical modeling of infectious diseases or economic analyses. We realize that this may have been biased both by our search terms which targeted such studies and by our inclusion criteria which selected only for those studies that had a quantitative outcome. 
However, we think that this could also be partly due to the fact that some of the topics addressed may be hard to implement in the field given their underlying complexity. Moreover, funding for such interdisciplinary endeavors may be hard to obtain, thus making modeling approaches a more feasible and economically viable option.

One of the greatest challenges of this review lay with the definition of $\mathrm{OH}$. The definition provided by the American Veterinary Medical Association (2008) was chosen to inform the review, and several examples were provided within the screening forms to ensure consistency in the interpretation of $\mathrm{OH}$. Despite this, the interpretation of some references was difficult. Therefore, it is possible that studies may have been excluded which according to other definitions may be considered $\mathrm{OH}$ or, conversely, included studies which may not be considered $\mathrm{OH}$. The recently published COHERE checklist for $\mathrm{OH}$ studies (Davis et al. 2017) should help with such future endeavors by setting a benchmark as to what should be considered a $\mathrm{OH}$ approach.

The final list of studies only included around $0.0025 \%$ of all screened references. This was expected given the broad search terms used. It was agreed that given the objective to identify those studies that described a $\mathrm{OH}$ approach (without necessarily containing the term $\mathrm{OH}$ ), the sensitivity of the search should be prioritized over the specificity. Despite the broad search terms, a certain publication bias is to be expected based on the selection of literature databases, although they were selected pertinent to the type of studies that were sought in the review. An information specialist who specializes in objective, structured reviews of the literature (DG) was consulted and involved in the process of this review to ensure that the most appropriate databases were searched. Furthermore, we attempted to identify relevant studies in the gray literature through our search verification, which included expert elicitation and review of relevant textbooks. Future work should prioritize investigating these alternative sources further, as it is possible that the expected positive publication bias could have affected the results obtained.

As our review question focused on quantitative outcomes, we excluded those studies which described qualitative outcomes of a $\mathrm{OH}$ approach, such as improved knowledge on health topics, changes in attitude or practices, or improved participation, which are a necessary preceding step to ensure uptake and implementation of interventions and practices (World Health Organization 2014). These outcomes may be harder to evaluate as they are often intangible and incommensurable. Yet they are important components of the overall societal benefit and should therefore be taken into consideration when making decisions regarding fund allocation for disease control programs or other interventions.

We note that during the full-text screening process we excluded 60 references which described a $\mathrm{OH}$ approach but not a quantitative outcome. This lack of reported outcomes is similar to findings reported by other recently published reviews (Häsler et al. 2014a; Baum et al. 2017) and underlines a gap in current published research, where missing quantification of the evidence may hinder the uptake of research findings. Additionally, while this review identified a numerous diversity of monetary and non-monetary terms, this diversity in itself may impede comparisons between studies. We therefore encourage harmonization of metrics to ensure that future research is both outcome-based and comparable, thus facilitating interpretation and implementation of findings based on $\mathrm{OH}$ approaches. It is important for a number of stakeholders to be involved in the decisionmaking process in relation to the prioritization of which outcomes should be consistently measured in studies employing a $\mathrm{OH}$ approach. All levels of decision-makers should be included in the process, from those in the field to those at the policy-making level. This will ensure that the most appropriate outcomes, and therefore the most likely to be successfully captured, are identified. It is suggested that structured objective frameworks such as the Delphi methodology (Okoli and Pawlowski 2004) and those employed by the James Lind Alliance (http://www.jla.nihr.ac. $\mathrm{uk} /$ ) be utilized for this purpose.

This review identifies a number of studies that may not have included terminology relating to $\mathrm{OH}$ but have employed a $\mathrm{OH}$ approach. Additionally, this is the first time that the quantitative outcomes of $\mathrm{OH}$ studies have been collectively reported, and therefore could provide an additional resource for policy-makers to utilize for similar $\mathrm{OH}$ research studies in the future. Future work should focus on investigating further the gray literature for other similar studies and the harmonization of metrics employed to determine the success of approaches across all $\mathrm{OH}$ studies.

\section{ACKNOWLEDGEMENTS}

Many thanks to Prof. Jakob Zinsstag (who helped to sow the idea for the review, and helped with defining the research question, search terms and protocol); Dr. Barbara Häsler (who helped with search terms and search verifica- 
tion); Ulrich Sperling (for his assistance with the preparation of the figures); and the European College of Veterinary Public Health for allowing us to embark on this project. This work has partially been supported by work from the COST Action TD1404 (Network for Evaluation of One Health) and supported by COST (European Cooperation in Science and Technology).

\section{OPEn Access}

This article is distributed under the terms of the Creative Commons Attribution 4.0 International License (http:// creativecommons.org/licenses/by/4.0/), which permits unrestricted use, distribution, and reproduction in any medium, provided you give appropriate credit to the original author(s) and the source, provide a link to the Creative Commons license, and indicate if changes were made.

\section{REFERENCES}

Aikins MK, Fox-Rushby J, D'Alessandro U, Langerock P, Cham K, New L, Bennett S, Greenwood B, Mills A (1998) The Gambian national impregnated bednet programme: costs, consequences and net cost-effectiveness. Social Science and Medicine 46:181191

Akhavan D, Musgrove P, Abrantes A, Gusmão RDA (1999) Costeffective malaria control in Brazil. Cost-effectiveness of a malaria control program in the Amazon Basin of Brazil, 19881996. Social Science and Medicine 49:1385-1399

American Veterinary Medical Association (2008) One Health: a new professional imperative. Final Report. Available: https:// www.avma.org/KB/Resources/Reports/Documents/onehealth_fi nal.pdf. Accessed 5 December 2014

Aubert MFA (1999) Costs and benefits of rabies control in wildlife in France. Revue Scientifique et Technique 18:533-543

Barrett MA, Bouley TA (2015) Need for enhanced environmental representation in the implementation of One Health. Ecohealth $12: 212-219$

Baum SE, Machalaba C, Daszak P, Salerno RH, Karesh WB (2017) Evaluating One Health: are we demonstrating effectiveness? One Health 3:5-10

Bauman AE, Russell SJ, Furber SE, Dobson AJ (2001) The epidemiology of dog walking: an unmet need for human and canine health. Medical Journal of Australia 175:632-634

Boden L, Auty H, Goddard P, Stott A, Ball N, Mellor D (2014) Working at the science-policy interface. Veterinary Record 174:165-167

Bögel K, Meslin FX (1990) Economics of human and canine rabies elimination: guidelines for programme orientation. Bulletin of the World Health Organization 68:281-291

Centre for Reviews and Dissemination (2009) Systematic reviews: CRD's guidance for undertaking reviews in health care. Avail- able: https://www.york.ac.uk/media/crd/Systematic_Reviews. pdf. Accessed 12 December 2016

Chan M (2014) Food safety must accompany food and nutrition security. Lancet 384:1910-1911

Cleaveland S, Lankester F, Townsend S, Lembo S, Lembo T, Hampson K (2014) Rabies control and elimination: a test case for One Health. Veterinary Record 175:188-193

Davis MF, Rankin SC, Schurer JM, Cole S, Conti L, Rabinowitz P, COHERE Expert Review Group (2017) Checklist for One Health epidemiological reporting of evidence (COHERE). One Health 17:14-21

Day MJ (2010) One Health: the small animal dimension. Veterinary Record 167:847-849

Díaz C (2012) Preventing dengue at the local level in Havana city. In: Ecohealth Research in Practice: Innovative Applications of an Ecosystem Approach to Health, Charron DF (editor), International Development Research Centre, pp 163-171

Dixon MA, Dar OA, Heymann DL (2014) Emerging infectious diseases: opportunities at the human-animal-environment interface. Veterinary Record 174:546-551

European Union Scientific Steering Committee (2015) The role of research in global food and nutrition security. Available: http:// europa.eu/expo2015/sites/default/files/files/FINAL_Expo-Discus sion-paper_lowQ(1).pdf. Accessed 12 December 2016

Fishbein DB, Miranda NJ, Merrill P, Camba RA, Meltzer M, Carlos ET, Bautista CF, Sopungco PV, Mangahas LC, Hernandez LM (1991) Rabies control in the Republic of the Philippines: benefits and costs of elimination. Vaccine 9:581-587

Fitzpatrick MC, Hampson K, Cleaveland S, Mzimbiri I, Lankester F, Lembo T, Meyers LA, Paltiel AD, Galvani AP (2014) Costeffectiveness of canine vaccination to prevent human rabies in rural Tanzania. Annals of Internal Medicine 160:91-100

Gatton ML, Cheng Q (2010) Interrupting malaria transmission: quantifying the impact of interventions in regions of low to moderate transmission. PLoS One 5: https://doi.org/10.1371/ journal.pone.0015149

Gellynck X, Messens W, Halet D, Grijspeerdt K, Hartnett E, Viaene J (2008) Economics of reducing Campylobacter at different levels within the Belgian poultry meat chain. Journal of Food Protection 71:479-485

Gibbs EP (2014) The evolution of One Health: a decade of progress and challenges for the future. Veterinary Record 174:85-91

Global Burden Disease (2015) DALYs and HALE Collaborators (2016) Global, regional, and national disability-adjusted lifeyears (DALYs) for 315 diseases and injuries and health life expectancy (HALE), 1990-2015: a systematic analysis for the Global Burden of Disease Study. Lancet 388:1603-1658

Goldbach SG, Alban L (2006) A cost-benefit analysis of Salmonella-control strategies in Danish pork production. Preventive Veterinary Medicine 17:1-14

Goodman CA, Coleman PG, Mills AJ (1999) Cost-effectiveness of malaria control in sub-Saharan Africa. Lancet 354:378-385

Goodman CA, Mnzava AE, Dlamini SS, Sharp BL, Mthembu DJ, Gumede JK (2001) Comparison of the cost and cost-effectiveness of insecticide-treated bednets and residual house-spraying in KwaZulu-natal South Africa. Tropical Medicine and International Health 6:280-295

Greter H, Jean-Richard V, Crump L, Béchir M, Alfaroukh IO, Schelling E, Bonfoh B, Zinsstag J (2014) The benefits of One Health for pastoralists in Africa. Onderstepoort Journal of Veterinary Research 81:1-9 
Hanoi Declaration (2015) The sustainable development goals: turning words into action. Available: http://www.ipu.org/confe/132/rpt-gendebate.htm. Accessed 29 March 2016

Häsler B, Gilbert W, Jones BA, Pfeiffer DU, Rushton J, Otte MJ (2012) The economic value of One Health in relation to the mitigation of zoonotic disease risks. Current Topics in Microbiology and Immunology 365:127-151

Häsler B, Cornelsen L, Bennani H, Rushton J (2014a) A review of the metrics for One Health benefits. Revue scientifique et technique 33:453-464

Häsler B, Hiby E, Gilbert W, Obeyesekere N, Bennani H, Rushton J (2014b) A One Health framework for the evaluation of rabies control programmes-a case study from Colombo city Sri Lanka. PLOS Neglected Tropical Diseases 8:e3270. https://doi. org/10.1371/journal.pntd.0003270

Havelaar AH, Mangen MJ, de Koeijer AA, Bogaardt MJ, Evers EG, Jacobs-Reitsma WF, van Pelt W, Wagenaar JA, de Wit GA, van der Zee H, Nauta MJ (2007) Effectiveness and efficiency of controlling Campylobacter on broiler chicken meat. Risk Analysis 27:831-844

Higgins JPT, Green S (2008) Cochrane handbook for systematic reviews of interventions, Chichester: Wiley Blackwell Press

Hodgson K, Darling M (2011) Zooeyia: an essential component of "One Health". Canadian Veterinary Journal 52:189-191

Jensen HG, Jensen JD (2013) Vaccination of poultry against Campylobacter in the EU-what are the benefits? Food Economics. http://dx.doi.org/10.1080/2164828X.2013.859142

Kangas S, Lyytikäinen T, Peltola J, Ranta J, Maijala R (2007) Costs of two alternative Salmonella control policies in Finnish broiler production. Acta Veterinaira Scandinavica 49. https://doi.org/ 10.1186/1751-0147-49-35

Karesh WB, Dobson A, Lloyd-Smith JO, Lubroth J, Dixon MA, Bennett M, Aldrich S, Harrington T, Formenty P, Loh EH, Machalaba C, Thomas MJ, Heymann DL (2012) Ecology of zoonoses: natural and unnatural histories. Lancet 380:19361945

Korsgaard H, Madsen M, Feld NC, Mygind J, Hald T (2009) The effects, costs and benefits of Salmonella control in the Danish table-egg sector. Epidemiology and Infection 137:828-836

Kushner RF, Blatner DJ, Jewell DE, Rudloff K (2006) The PPET study: people and pets exercising together. Obesity 14:17621770

Lake RJ, Horn BJ, Dunn AH, Parris R, Green FT, McNickle DC (2013) Cost-effectiveness of interventions to control Campylobacter in the New Zealand poultry meat food supply. Journal of Food Protection 76:1161-1167

Mangen M-JJ, Havelaar AH, Poppe KP, de Wit GA, CARMA Project Team (2007) Cost-utility analysis to control Campylobacter on chicken meat - dealing with data limitations. Risk Analysis 27:815-830

Manlove KR, Walker JG, Craft ME, Huyvaert KP, Joseph MB, Miller RS, Nol P, Patyk KA, O’Brien D, Walsh DP, Cross PC (2016) "One Health" or three? Publication silos among the One Health disciplines. PLoS Biology 14(4):e1002448. https://doi.org/ 10.1371/journal.pbio.1002448

McConnell KJ, Gubler DJ (2003) Guidelines on the cost-effectiveness of larval control programs to reduce dengue transmission in Puerto Rico. Revista Panamericana de Salud Pública 14:9-16

Miller GY, Liu X, McNamara PE, Barber DA (2005) Influence of Salmonella in pigs preharvest and during pork processing on human health costs and risks from pork. Journal of Food Protection 68:1788-1798

Mills D, Hall S (2014) Animal-assisted interventions: making better use of the human-animal bond. Veterinary Record 174:269-273

Min B, Allen-Scott LK, Buntain B (2013) Transdisciplinary research for complex One Health issues: a scoping review of key concepts. Preventive Veterinary Medicine 112:222-229

Ministère de la Santé et de la Protection Sociale Française (1989) Étude coût-bénéfice de la prophylaxie médicale de la rage vulpine. Bulletin Epidemiologique Hebdomadaire 36:145-148

Minutes of the expert workshop (Leverhulme Centre for Integrative Research on Agriculture and Health, Royal Veterinary College, SOAS University of London, London School of Hygiene and Tropical Medicine) (2013) One Health benefits: key inputs to create an economic evidence base. Available: http:// www.lcirah.ac.uk/sites/default/files/Metrics\%20for\%20One $\% 20$ Health\%20benefits\%20workshop\%20report\%20final.pdf. Accessed 5 December 2014

Moher D, Liberati A, Tetzlaff J, Altman DG, The PRISMA Group (2009) Preferred reporting items for systematic reviews and metaanalyses: the PRISMA statement. PLoS Med 6(7): e1000097. https://doi.org/10.1371/journal.pmed000097. Accessed 12 December 2016

Mueller DH, Wiseman V, Bakusa D, Morgah K, Daré A, Tchamdja P (2008) Cost effectiveness analysis of insecticidetreated net distribution as part of Togo integrated child health campaign. Malaria Journal 7. https://doi.org/10.1186/14752875-7-73

Mulligan J-A, Yukich J, Hanson K (2008) Costs and effects of the Tanzanian national voucher scheme for insecticide-treated nets. Malaria Journal 7. https://doi.org/10.1186/1475-2875-7-32

Murray M, Holmes P, Wright N, Jarrett O, Kennedy P (2014) History of One Health and One Medicine. Veterinary Record 174:227

Ocampoa CB, Minaa NJ, Carabalía M, Alexandera N, Osorio L (2014) Reduction in dengue cases observed during mass control of Aedes (Stegomyia) in street catch basins in an endemic urban area in Colombia. Acta Tropica 132. https://doi.org/10.1016/j. actatropica.2013.12.019

Okoli C, Pawlowski SD (2004) The Delphi method as a research tool: an example, design considerations and applications. Information \& management 42:15-29

Orellano PW, Pedroni E (2008) Cost-benefit analysis of vector control in areas of potential dengue transmission. Revista Panamericana de Salud Pública 24:113-119

Oura C (2014) A One Health approach to the control of zoonotic vectorborne pathogens. Veterinary Record 174:398-402

Persson U, Jendteg S (1992) The economic impact of poultryborne salmonellosis: how much should be spent on prophylaxis? International Journal of Food Microbiology 15:207-213

Pinto HDBF, Assis A, Pinto RM, Monteiro SLP, Pinheiro SR (2011) Avaliacao do custo-beneficio das atividades de prevencao da raiva humana e das atividades de controle da raiva caninca no municipio de mogi guacu, estado de Sao Paulo, no periodo de 2000 a 2004. Arquivo Brasileiro de Medicina Veterinária e Zootecnia 18:112-122

Pulkki-Brännström A, Wolff C, Brännström N, Skordis-Worrall J (2012) Cost and cost effectiveness of long-lasting insecticidetreated bed nets-a model-based analysis. Cost Effectiveness and Resource Allocation 10. https://doi.org/10.1186/1478-7547-10-5 
Queenan K, Häsler B, Rushton J (2016) A One Health approach to antimicrobial resistance surveillance: is there a business case for it? International Journal of Antimicrobial Agents 48:422-427

Rabinowitz PM, Odofin L, Dein FJ (2008) From "us vs. them" to "shared risk": can animals help link environmental factors to human health? Ecohealth 5:224-229

Riedel N, Vounatsou P, Miller JM, Gosoniu L, Chizema-Kawesha K, Mukonka V, Steketee RW (2010) Geographical patterns and predictors of malaria risk in Zambia: Bayesian geostatistical modelling of the 2006 Zambia national malaria indicator survey (ZMIS). Malaria Journal 9(37). https://doi.org/10.1186/14752875-9-37

Roberts RJ (2014) History of One Health and One Medicine. Veterinary Record 174:283

Romero-Barrios P, Hempen M, Messens W, Stella P, Hugas M (2013) Quantitative microbiological risk assessment (QMRA) of food-borne zoonoses at the European level. Food Control 29:343-349

Roth F, Zinsstag J, Orkhon D, Chimed-Ochir G, Hutton G, Cosivi O, Carrin G, Otte J (2003) Human health benefits from livestock vaccination for brucellosis: case study. Bulletin of the World Health Organization 81:867-876

Rushton J, Häsler B, De Haan N, Rushton R (2012) Economic benefits or drivers of a "One Health" approach: why should anyone invest? Onderstepoort Journal of Veterinary Research 79. https://doi.org/10.4102/ojvr.v79i2.461

Rusthon J (2009) The economics of animal health and production, Oxfordshire: CABI editions

Schelling E, Bechir M, Ahmed MA, Wyss K, Randolph TF, Zinsstag J (2007) Human and animal vaccination delivery to remote nomadic families, Chad. Emerging Infectious Diseases 13:373379

Shaw APM, Wint GRW, Cecchi G, Torr SJ, Mattioli RC, Robinson TP (2015) Mapping the benefit-cost ratios of interventions against bovine trypanosomosis in Eastern Africa. Preventive Veterinary Medicine 4:406-416

Shwiff SA, Nunan CP, Kirkpatrick KN, Shwiff SS (2011) A retrospective economic analysis of the Ontario red fox oral rabies vaccination programme. Zoonoses Public Health 58:169-177

Shwiff S, Aenishaenslin C, Ludwig A, Berthiaume P, Bigras-Poulin M, Kirkpatrick K, Lambert L, Bélanger D (2012) Bioeconomic Modelling of Raccoon Rabies Spread Management Impacts in Quebec, Canada. Transboundary and Emerging Diseases 60:330337

Sherman DM (2010) A global veterinary medical perspective on the concept of One Health: focus on livestock. Institute for Laboratory Animal Research Journal 51:281-287

Singh P (2017) One Health approach to tackle antimicrobial resistance in South East Asia. BMJ. https://doi.org/10.1136/bmj. j3625

Smithuis FM, Kyaw MK, Phe UO, van der Broek I, Katterman N (2013) The effect of insecticide-treated bed nets on the incidence and prevalence of malaria in children in an area of unstable seasonal transmission in western Myanmar. Malaria Journal 12. https://doi.org/10.1186/1475-2875-12-363

Stärk KD, Kuribreña MA, Dauphin G, Vokaty S, Ward MP, Wieland B, Lindberg A (2015) One Health surveillance-more than a buzz word? Preventive Veterinary Medicine 120:124-130

Suaya JA, Shepard DS, Chang MS, Caram M, Hoyer S, Socheat D, Chantha N, Nathan MB (2007) Cost-effectiveness of annual targeted larviciding campaigns in Cambodia against the dengue vector Aedes aegypti. Tropical Medicine and International Health 12:1026-1036

Sundström K, Wahlström H, Ivarsson S, Lewerin SS (2014) Economic effects of introducing alternative Salmonella control strategies in Sweden. PLoS One 15(9):e96446. https://doi.org/10. 1371/journal.pone.0096446

Tenzin Wangdi K, Ward MP (2012) Human and animal rabies prevention and control cost in Bhutan, 2001-2008: the costbenefit of dog rabies elimination. Vaccine 31:260-270

The FAO-OIE-WHO Collaboration (2010) Sharing responsibilities and coordinating global activities to address health risks at the animal-human-ecosystems interfaces. A tripartite concept note. Available: http://www.who.int/influenza/resources/docu ments/tripartite_concept_note_hanoi_042011_en.pdf. Accessed 22 December 2014

The World Bank (2012) People, pathogens and our planet. Volume 2. The economics of One Health. Available: https://open knowledge.worldbank.org/bitstream/handle/10986/11892/69145 0ESW0whit0D0ESW120PPPvol120web.pdf. Accessed 7 November 2017

Townsend SE, Sumantra IP, Pudjiatmoko, Bagus GN, Brum E (2013) Designing programs for eliminating canine rabies from islands: Bali, Indonesia as a case study. PLOS Neglected Tropical Diseases 7:e2372. https://doi.org/10.1371/journal.pntd.0002372

Tschopp R, Hattendorf J, Roth F, Choudhury AA, Shaw A, Aseffa A, Zinsstag J (2013) Cost estimate of bovine tuberculosis to Ethiopia. Current Topics in Microbiology and Immunology 365: 249-268

Tsunoda T, Kawada H, Huynh TT, Luu LL, Le SH, Tran HN, Vu HT, Le HM, Hasebe F, Tsuzuki A, Tagaki, M (2013) Field trial on a novel control method for the dengue vector, Aedes aegypti by the systematic use of Olyset Net and pyriproxyfen in Southern Vietnam. Parasites and Vectors 6. https://doi.org/10. 1186/1756-3305-6-6

Uhaa IJ, Dato VM, Sorhage FE, Beckley JW, Roscoe DE, Gorsky RD, Fishbein DB (1992) Benefits and costs of using an orally absorbed vaccine to control rabies in raccoons. Journal of the American Veterinary Medical Association 201:1873-1882

United Nations (2014) World Economic Situation and Prospects 2014. Available: http://www.un.org/en/development/desa/policy/ wesp/wesp_current/2014wesp_country_classification.pdf. Accessed 17 November 2017

United Nations (2015) Sustainable Development Goals. Available: http://www.un.org/sustainabledevelopment/sustainable-develop ment-goals/. Accessed 29 March 2016

Van Noorden R (2015) Interdisciplinary research by the numbers. Nature 525:306-307

Wall P (2014) One Health and the food chain: maintaining safety in a globalised industry. Veterinary Record 174:189-192

Wegener HC, Hald T, Lo Fo Wong D, Madsen M, Korsgaard H, Bager F, Gerner-Smidt P, Mølbak K (2003) Salmonella control programs in Denmark. Emerging Infectious Diseases 9:774-780

Woods A, Bresalier M (2014) One health, many histories. Veterinary Record 174:650-654

World Conservation Society (2004) The Manhattan Principles. Available: http://www.cdc.gov/onehealth/pdf/manhattan/ twelve_manhattan_principles.pdf. Accessed 22 December 2014

World Health Organization (2007) WHO releases new guidance on insecticide-treated mosquito nets. Available at: http://www. who.int/mediacentre/news/releases/2007/pr43/en/. Accessed 7 November 2017 
World Health Organization (2014) The Control of Neglected Zoonotic Diseases: from advocacy to action. Available: http:// www.who.int/neglected_diseases/ISBN9789241508568_ok.pdf. Accessed 29 March 2016

World Health Organization Global Burden of Foodborne Diseases (2015) Available: http://www.who.int/foodsafety/areas_work/ foodborne-diseases/ferg/en/. Accessed 11 December 2016

World Health Organization (2016a) Estimates for 2000-2012. Available: http://www.who.int/healthinfo/global_burden_dis ease/estimates/en/index2.html. Accessed 11 December 2016

World Health Organization (2016b) WHO Director-General summarizes the outcome of the Emergency Committee regarding clusters of microcephaly and Guillain-Barré syndrome. Available: http://www.who.int/mediacentre/news/state ments/2016/emergency-committee-zika-microcephaly/en/. Accessed 29 March 2016

World Health Organization (2017) Fact sheets on sustainable development goals: health targets. Antimicrobial Resistance. Available at: http://www.euro.who.int/_data/assets/pdf_file/ 0005/348224/Fact-sheet-SDG-AMR-FINAL-07-09-2017.

pdf?ua $=1$. Accessed 8 November 2017
Yhdego M, Majura P (1988) Malaria control in Tanzania. Environment International 14:479-483

Young I, Waddell L, Sanchez J, Wilhelm B, McEwen SA, Rajić A (2014) The application of knowledge synthesis methods in agrifood public health: recent advancements, challenges and opportunities. Preventive Veterinary Medicine 113:339-355

Zinsstag J, Dürr S, Penny MA, Mindekem R, Roth F, Menendez Gonzalez S, Naissengar S, Hattendorf J (2009) Transmission dynamics and economics of rabies control in dogs and humans in an African city. Proceedings of the National Academy of Sciences of the United States of America 106:14996-15001

Zinsstag J, Schelling E, Roth F, Bonfoh B, de Savigny D, Tanner M (2007) Human benefits of animal interventions for zoonosis control. Emerging Infectious Diseases 13:527-531

Zinsstag J, Schelling E, Waltner-Toews D, Tanner M (2011) From "One Medicine" to "One Health" and systemic approaches to health and well-being. Preventive Veterinary Medicine 101:148156 